\title{
"Efficiency and corporate governance of a state-owned enterprise: the case of the Tunisian national railway company"
}

\begin{tabular}{|c|c|}
\hline AUTHORS & Afef Bouattour \\
\hline ARTICLE INFO & $\begin{array}{l}\text { Afef Bouattour (2020). Efficiency and corporate governance of a state-owned } \\
\text { enterprise: the case of the Tunisian national railway company. Economics of } \\
\text { Development, 19(1), 23-34. doi:10.21511/ed.19(1).2020.03 }\end{array}$ \\
\hline DOl & http://dx.doi.org/10.21511/ed.19(1).2020.03 \\
\hline RELEASED ON & Friday, 17 April 2020 \\
\hline RECEIVED ON & Thursday, 26 December 2019 \\
\hline \multirow[t]{2}{*}{ ACCEPTED ON } & Thursday, 05 March 2020 \\
\hline & $(\mathrm{cc}) \mathrm{EY}$ \\
\hline LICENSE & $\begin{array}{l}\text { This work is licensed under a Creative Commons Attribution } 4.0 \text { International } \\
\text { License }\end{array}$ \\
\hline JOURNAL & "Economics of Development" \\
\hline ISSN PRINT & $1683-1942$ \\
\hline ISSN ONLINE & $2304-6155$ \\
\hline PUBLISHER & LLC "Consulting Publishing Company "Business Perspectives" \\
\hline FOUNDER & Simon Kuznets Kharkiv National University of Economics \\
\hline
\end{tabular}

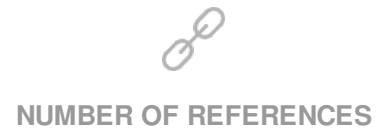

22

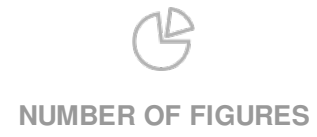

5
NUMBER OF TABLES

2

(C) The author(s) 2021. This publication is an open access article. 


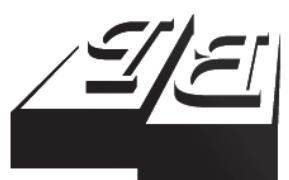

BUSINESS PERSPECTIVES

Publisher

LLC "CPC "Business Perspectives" Hryhorii Skovoroda lane, 10, Sumy, 40022, Ukraine www.businessperspectives.org

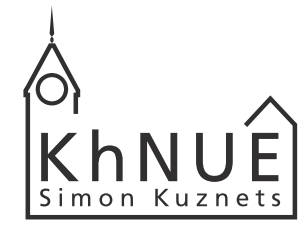

\section{S. KUZNETS KHNUE}

Founder

Simon Kuznets Kharkiv National University of Economics, Nauky avenue, 9-A, Kharkiv, 61166,

Ukraine

http://www.hneu.edu.ua/

Received on: 26th of December, 2019 Accepted on: 5th of March, 2019 Published on: 17th of April, 2020

\section{(c) Afef Bouattour, 2020}

Afef Bouattour, Higher Institute of Business Administration of Sfax, University of Sfax, Tunisia.

\section{EFFICIENCY AND CORPORATE GOVERNANCE OF A STATE-OWNED ENTERPRISE: THE CASE OF THE TUNISIAN NATIONAL RAILWAY COMPANY}

\begin{abstract}
The inefficiency of the State-Owned Enterprise is a matter of concern to economists. Among the studies carried out, those based on the theory of corporate governance were found. However, most of these studies focus on comparing the public enterprise governance with that of the private one. Thus, this article departs from this comparison towards an analysis of the governance of public enterprises to understand its inefficiency by examining the case of the Tunisian Railway Company. Starting with the approach used by Lehmann et al. (2002), it uses the Data Envelopment Analysis to evaluate the effectiveness of a governance system. The governance scores obtained were used to explain the efficiency variables for each year in the sample using regression in temporal data. The analysis revealed significant problems in governance mechanisms related to the lack of information transparency, weaknesses in functions of the government shareholder, and, in particular, control system failures.
\end{abstract}

Keywords

JEL Classification

public enterprise, efficiency, corporate governance, data envelopment analysis, governance system

L30, L32, L92, O18, R40

Афеф Буатур (Туніс)

\title{
ЕФЕКТИВНІСТЬ ТА КОРПОРАТИВНЕ УПРАВЛІННЯ ДЕРЖАВНИМ ПІДПРИЕМСТВОМ НА ПРИКЛАДІ ТУНІСЬКОÏ НАЦІОНАЛЬНОÏ ЗАЛІЗНИЧНОЇ КОМПАНІЇ
}

\begin{abstract}
Анотація
Неефективність державного підприємства викликає занепокоєння економістів. Серед проведених досліджень знайдено такі, що грунтуються на теорії корпоративного управління. Однак більшість цих досліджень присвячено порівнянню управління державним підприємством і приватним. Взявши за приклад залізничну компанію Тунісу, автори статті відходять від цього порівняння та аналізують питання управління державним підприємством, щоб з'ясувати причини його неефективності. Почавши з підходу Леманна та ін. (2002), вони застосовують метод аналізу охоплення даних з метою оцінки ефективності системи управління. Отримані результати використано для пояснення змінних ефективності за кожен рік у вибірці з використанням регресії тимчасових даних. Виявлено значні проблеми в механізмах управління, пов’язані з непрозорістю інформації, слабкістю функцій державиакціонера та, зокрема, збоями в системах управління.
\end{abstract}

\section{Ключові слова державне підприємство, ефективність, корпоративне управління, аналіз охоплення даних, система управління \\ Класифікація JEL L30, L32, L92, O18, R40}

This is an Open Access article, distributed under the terms of the Creative Commons Attribution 4.0 International license, which permits unrestricted re-use, distribution, and reproduction in any medium, provided the original work is properly cited.

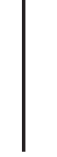




\section{INTRODUCTION}

Since the 1970s, the inefficiency of State-Owned Enterprise has been the subject of several theoretical and empirical studies (Lin et al., 1998; Shleifer \& Vishny, 1994; Boycko et al., 1996). It was only in the late 1980s that studies on the efficiency of public enterprises, based on the theory of corporate governance, appeared (Charreaux, 1996). However, most of these studies fit into a logic of comparison of the public enterprise governance to the private one (Nellis, 1994; Charreaux, 1996). In addition, studies focusing only on the governance of public companies remain limited (Daiser, Ysa \& Schmitt, 2017; Grossi et al., 2015). It is in this sense that this article moves away from the public / private comparison and tends towards an analysis of the governance of the public company in order to understand its inefficiency.

The aim of this research is to find out whether a failure in the governance mechanisms can explain the inefficiency of the State-Owned Enterprise. This study adopted the hypothetico-deductive type aproach, as it makes it possible to exploit theoretical results on the link between inefficiency and corporate governance. The line of research focuses on the use of governance theories to explain the inefficiency of the State-Owned Enterprise. However, the article considers that inefficiency follows an iterative and cumulative process whose explanation can only be composite.

Due to the exploratory character of this work in the Tunisian context, author chose the Tunisian National Railways Company (SNCFT) as a means of access to reality. The reason for this choice lies in the fact that railway undertakings are becoming inefficient in many countries, both underdeveloped and developed. In addition, the railway undertakings by their specificities are an example of State-Owned Enterprises in difficulty or even in a state of "virtual bankruptcy".

The rest of the paper consists of five sections. Section 2 recalled the origin of the theory of governance and its theoretical basis. Section 3 presents the methodology adopted for data analysis by specifying the econometric model. Section 4 presents the results obtained and their analysis. Section 5 presents discussion on SNCFT corporate governance problems. Finally, section 6 provides an overview of the implications of the analysis and the prospects for further research.

\section{LITERATURE REVIEW}

The issue of corporate governance sparked the interest of researchers in several areas (economic, political, management...). Governance, as pointed out by Charreaux (2006), has become inseparable from the economic development.

The theory of governance tends to determine the way in which people are governed. The theme of governance has its origins in the debate initiated by Berle and Means (1932), who attribute the problem of governance to the separation of the control function, which is the prerogative of the owners of the decision-making function that returns to the leaders. This property-decision separation occurred at the beginning of the century in large American companies. Given the failure of the control systems, this ownership-decision split has led to a deterioration of the efficiency and a stripping of the shareholders.

According to Charreaux (2006), the main corporate governance theories linked to the paradigm of efficiency relate to a certain model of creation and distribution of value by the organization. Referring to this author, we can distinguish three governance models that explain the efficiency of organizations differently: the financial model, the contractual partnership model and the cognitive model of governance.

\subsection{The financial model of governance: the profitability of financial investment Pro- tection}

The first model is rooted in the theory of the Agency. The financial model of governance is based on the analysis conducted by Jensen and Meckling (1976). They see the firm as a knot of contracts established between the different partners whose interests diverge, causing conflict, and therefore the agency costs. Jensen and Meckling reduce 
agency relationships to relationships between managers and shareholders on the one hand, and between the firm and financial creditors on the other. This approach is the foundation of the shareholder financial design that still feeds the current debates. However, this design limits the governance system to mechanisms that align the interests of executives with those of shareholders (Rezaee, 2019).

In this perspective, as pointed out by Shleifer and Vishny (1997), the governance system's role is to protect the profitability of financial investment. The Governance system includes firm's internal control mechanisms resulting from shareholders, the Board of directors or executives as well as external mechanisms related to the market fonctionning.

These different mechanisms work together while being complementary or substitutable. It is in this sense that the role of these mechanisms differs according to the type of organization. Indeed, when it comes to firm managerial, market leaders becomes a mechanism of weight. Leaders seeking always to improve their value in this market by maximizing the firm's shareholder value. However, other internal mechanisms are required to ensure the maximization of the value. For example, the board of directors, or the control of managers, makes it possible to improve the efficiency of managers through the incentive systems they create.

Other mechanisms such as the takeover market can be used as a last resort, especially when losses are important. The origin of these impairment losses may differ depending on the nature of the conflicts of interest. The rooting of the leader behavior might be causing a loss of value in contributing to the increase in agency costs. It is as well as the governance system must reduce this loss of value through its control mechanisms. However, the costs of these mechanisms must be less than the gains that they allow. In some cases, the reduction of the decision-making latitude of the leader could be rather rather source of a lower efficiency, and therefore loss of value source.This financial model of governance, which highlights financial investors, and considers the shareholders as the only remaining creditors, not so interested in the alignment of the interests of managers with those of shareholders.

\subsection{The contractual model of governance: Inefficient conflict resolution}

The contractual model calls into question the status of residual creditor only granted to the shareholders. This challenge encourages the review of the problem of Division of the corporate pension. Indeed, it is the perception of a portion of the remuneration that could encourage other partners to create value. The second contractual partnership model calls into question the residual creditor status only granted to shareholders. This challenge encourages the reconsideration of the problem of sharing the organizational rent. Indeed, it is the perception of part of the rent that could encourage other partners to create value. It is in a sense that the distribution of this rent between the different factors of production, thus reaching the status of residual creditors, explains the effect of governance on the creation of value.

The governance system thus appears as the set of constraints that govern the negotiation for the sharing of the rent, taking place ex post between the different partners. The origin of this conception found in the theory of incomplete contracts, defines the property, not only by the residual decision rights, but also by the appropriation of the residual gains. It is thus possible to consider all the participants in the node of productive contracts as residual creditors. Managers and employees, who are attributed residual decision-making power, receive a portion of the organizational rent and are thus better incentivized to make efforts. Expanding ownership to all participants emphasizes the importance of human capital, which is central to the study of changing the nature of the firm in the new economy (Hayden and Bodie 2019). Indeed, the firm today differs considerably from the firm in Berle and Means and the biggest difference is the growing importance of human capital.

Given the change in the nature of the firm, the focus of governance must extend to the study of the mechanisms that give the firm the power to provide incentives for human capital. Thus, the study of governance must go beyond the analysis of Berle and Means (1932). In fact, the latter is limited to determining who the owners are, and whether the real owners can exercise their rights adequately. As a result, property rights appear stronger than management. 
However, the consideration of the role of managers in the production of the organizational rent, accounts for the managerial rent due to their specific skills. In addition, the capital associated with the specific skills of employees contributes to the production of the organizational rent. The system of governance is thus a way of protecting the value of the human capital of employees (Clarke and Branson, 2012). The partnership approach leads to studying the governance system throw its capacity to create partnership value, which requires the definition of organizational rent. However, this partnership model of governance is mainly limited to the resolution of conflicts of interest and the appropriation of rent, neglecting the cognitive aspects raised by the third model of governance.

\subsection{The cognitive model of governance: Role of human capital as an efficient vector}

The third model focuses on productive dynamics. According to Langlois and Foss (1999), contractual theories neglect the productive dimension of the construction of rents. It is not enough to converge interests, but we must also focus on qualitative coordination, mainly related to the competence and cognitive patterns of different partners. This cognitive approach considers the firm as a collection of knowledge that is not limited to the collection of information, but extends to the interpretation made of this information by individuals according to the cognitive models they have followed. By taking into account cognitive aspects in value creation, the firm has a sustainable profitability (Foss and Jensen, 2018). In addition, the role of the governance system goes beyond conflict resolution, and provides the greatest potential for value creation through organizational learning and innovation. Thus, these different governance models show that the micro theories of governance are moving more and more towards the consideration of the role of human capital as a vector of creation of organizational value in modern enterprises, characterized by separation of ownership and control functions.

\section{METHODOLOGY}

Starting from the approach used by Lehmann et al. (2002), our method uses two stages:

- apply the Data Envelopment Analysis (DEA) technique to our sample in order to evaluate the effectiveness of the governance system, to obtain an efficiency score of the governance practices for each year of our sample;

- use the governance scores thus obtained as variables that explain the performance of each year of our sample by means of a temporal data regression.

Based on linear programming, the DEA method makes it possible to identify empirical production functions. Based on microeconomic theory, this méthod allows comparing all units that are similar, while simultaneously taking several dimensions. Thus, it is from the point of view of best practice that it determines the efficiency frontier. Each unit is considered a Decision Making Unit (DMU, in our case it is a year), which transforms "inputs" into "outputs".

The score for efficiency in the presence of several factors of inputs and outputs defined as follows:

$$
\text { Efficiency }=\frac{\text { weighted sum of the outputs }}{\text { weighted sum of the inputs }} \text {. }
$$

Assuming that there are $\mathrm{n}$ DMU, each with $\mathrm{m}$ inputs and s outputs, the relative efficiency of a DMU test score $\mathrm{p}$ is obtained by solving the model, proposed by Charnes et al. (1978) following:

$$
\begin{array}{ll}
\max & \sum_{k=1}^{s} v_{k} y_{k p} / \sum_{j=1}^{m} u_{j} x_{j p}, \\
\text { s.c. } & \sum_{k=1}^{s} V_{k} y_{k i} / \sum_{j=1}^{m} u_{j} x_{j i} \leq 1 ; \quad V_{k}, u_{j} \geq 0 ; \forall k, j,
\end{array}
$$

where $k=1, \ldots, s, j=1, \ldots, m, i=1, \ldots, n, Y_{K i}$ is the amount of output produced by MISP $i, x_{j p}$ quantity of input product by DMU $i, V_{K}$ weight given to output $k$ and $u_{j}$ weighting given to the input $j$. 
$\max \sum_{k=1}^{s} V_{k} y_{k p}$

s.c. $\sum_{j=1}^{m} u_{j} X_{j p}=1 ; \sum_{k=1}^{s} V_{k} y_{k i}-\sum_{j=1}^{m} u_{j} X_{j i} \leq 0 ; \quad v_{k}, u_{j} \geq 0 ; \forall k, j$.

In order to identify the relative efficiency scores of all DMUs the above problem is executed $\mathrm{n}$ times. Each DMU thus chooses the weights of inputs and outputs that maximize its efficiency score. In general, a DMU will be considered effective if it gets a score of 1 . Therefore, it will be considered ineffective if the score is less than 1 . The DEA method identifies a set of effective units that corresponds to each DMU. For each inefficient DMU, the DEA identifies a set of effective units, which suit him and can constitute reference points for comparison. The dual problem presented in (4) gives the referencing.

$\min \theta$,

s.c. $\sum_{i=1}^{n} \lambda_{i} X_{j i}-\theta X_{j p} \leq 0 ; \sum_{i=1}^{n} \lambda_{i} y_{k i}-y_{k p} \geq 0 ; \quad \lambda_{i} \geq 0 ; \forall i$.

With effective governance structures, the management of company is more efficient. As a result, it is more likely to make the best investments and strategic decisions, resulting in higher profitability.

In order to measure the efficiency of the governance systems of the SNCFT by DEA method, we will choose the inputs and the outputs. Like Lehmann et al. (2002), this study has chosen as inputs the ownership structure (measured by the productivity of the labor factor (assessed by: work/Production) and the financial structure (measured by the net debt ratio = Net Debt / Equity). Regarding the outputs, this analysis have selected intensity capital (investment in proportion to the production) and the growth of the turnover.

Inputs:

Concentration of ownership (CP): In analysis, mesure the concentration of the property by the productivity of the labor force in relation to the overall production measured by the operating revenues.

Financial structure (SF): For the financial structure, this paper will consider the debt ratio defined as (Total debt / Total assets). The company is all the more indebted as this ratio is high.

Outputs:

The investment and growth of the firm's turnover reflect the quality of the governance practices and their efficiency, insofar as they inform us, in case of abuse of the managerial discretion of the overinvestment in unprofitable projects (Bednar et al., 2015).

Investment (INV) or capital intensity (K / Y) defined as the annual expenditure of assets divided by total assets (Total non-financial assets / Total assets) (Lehmann et al., 2004).

Turnover growth (TCA) is defined as the logarithm of the annual turnover change, Log (CAn - CAn-1) (Lehmann et al., 2004).

\section{RESULTS}

In this section, study consider the estimation by the DEA method of a governance index composed of two inputs and two outputs. Thus, will begin by presenting these variables. Indeed, and according to Chart 1 , author record a considerable drop in the average productivity of work along the study period. This means a considerable increase in the ratio $(\mathrm{L} / \mathrm{Y})$, which shows that one hour of work always uses more equipment to produce more service at the 
level of our society. This translates into a secular decline in labor productivity, which does not allow for a steady improvement in real wages and living standards. On average, this productivity is around 8.2 with a standard deviation almost half of 3.9 (see Table 1).

This lack of labor productivity has led to considerable losses leading to the increase in the ratio of debt to equity presented in Chart 2. This ratio assesses the debt capacity of the company and makes it possible to verify that the amount of the company's debt is not too large compared to the amount of equity (53.2\% with a standard deviation of 18\%). For our case, the higher the rate, the more the SNCFT is in debt. The ratio is less than 1; otherwise the company no longer has room to maneuver in terms of recourse to external financing.

Capital intensity is equal to the ratio of economic assets on the turnover. It measures the amount of capital committed for a given turnover. It also corresponds to the inverse of the rate of rotation of the economic assets. Indeed, the absence of a clear trend in the evolution of the capital-production report $(K / Y)$ along the study period (see chart 3), means that the same amount of equipment makes roughly the same volume of production.

It is therefore necessary to expect the same absence of trend in the evolution of the rate of return of capital. Income related to the determination of capital increases only if the capital stock (Investment) grows.

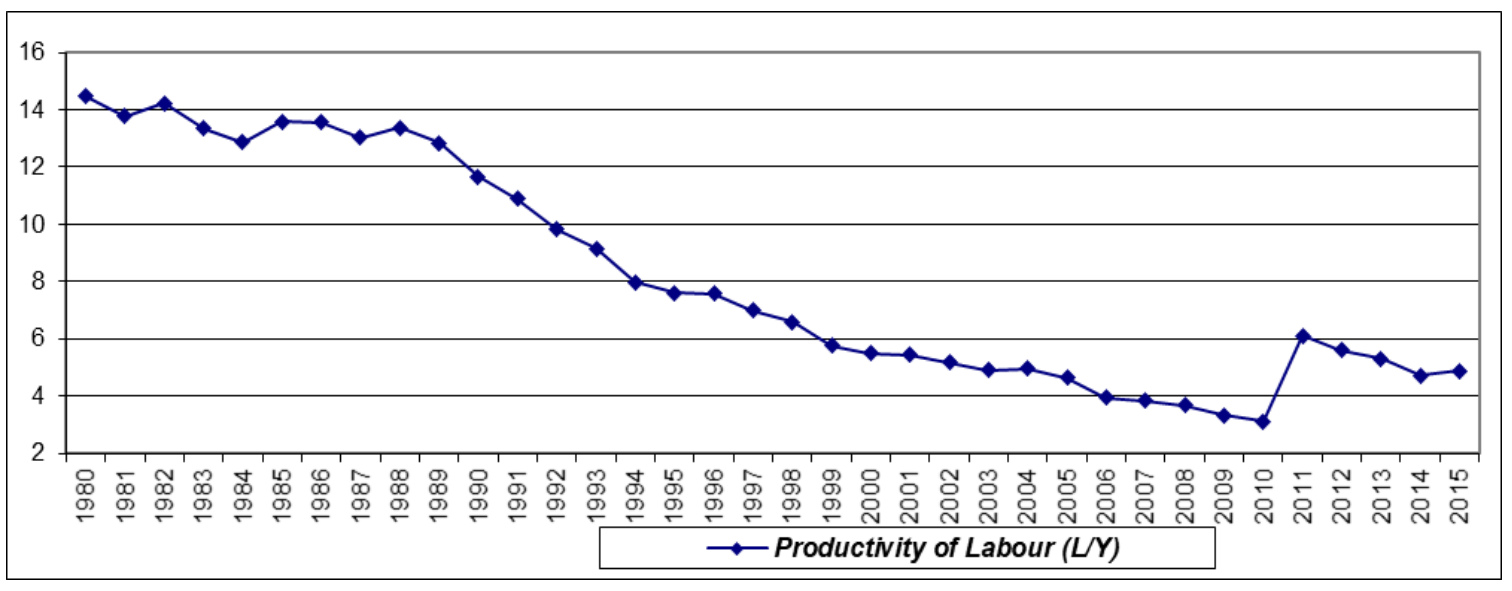

Source: Estimates of the author of the database.

Figure 1. Evolution of the average productivity of labour

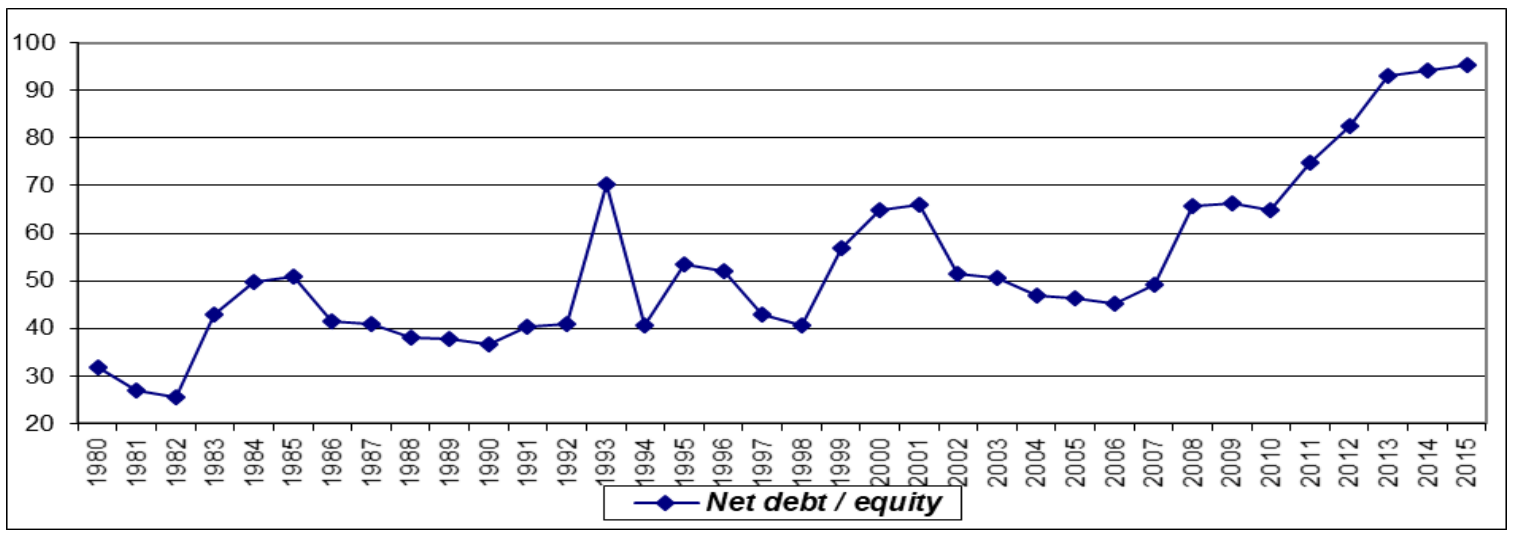

Source: Estimates of the author of the database.

Figure 2. Evolution of the ratio of debt to equity 
Table 1. Descriptive analysis of the inputs and outputs of the DEA model

Source: Estimates of the author of the database.

\begin{tabular}{|c|c|c|c|c|}
\hline Designation & $\begin{array}{c}\text { Labor productivity } \\
(\mathrm{L} / \mathrm{Y})\end{array}$ & Net debt/ equity & $\begin{array}{c}\text { Capital intensity } \\
(\mathrm{K} / \mathrm{Y})\end{array}$ & $\begin{array}{c}\text { Growth of the } \\
\text { turnover }\end{array}$ \\
\hline Average & 8.17 & 53.27 & 56.48 & 1.48 \\
\hline Standard deviation & 3.88 & 18.04 & 46.15 & 11.32 \\
\hline Minimum & 3.12 & 25.68 & 17.77 & -57.83 \\
\hline Maximum & 14.48 & 95.38 & 208.11 & 20.22 \\
\hline
\end{tabular}

The increase from 2008 has given an overall average of $56.5 \%$ but with a deviation high of $46 \%$, in fact, with a minimum capital intensity of $17.77 \% 1992$ and maximum intensity of $208.1 \%$ in 2012 . However, this intensity was low since the 1980s until the middle of the 2000s, from which there has been a continuous positive development up to the year 2010. About evolution that began in the mid-2000s, she finds its justification in the effects of the reforms carried out by the State. However the recorded fall in 2011 is explained in political and social disruption experienced by the country in 2011 (successive strikes, sit-ins), which led to a rail activity characterized by a significant drop in traffic, especially for phosphate and freight. With regard to the maximum value recorded in 2012, it is not significant in the sense that it simply reflects a political strategy, it is obvious that this increase could not last and will be followed by a decrease of the following years reaching $62.48 \%$ in 2015 .

The growth in turnover therefore does not allow the accumulation of technological capital, in other words increasing the stock of scientific and technical knowledge that used in production. As a result, the growth of SNCFT is not at the root of technical progress and increasing returns to scale, which in turn will not favor higher production (see Chart 4). Indeed, the average growth rate is low of $1.48 \%$ with a standard deviation too high of $11.3 \%$. This is mainly due to the sharp drop in 2011, which reached a negative rate of $-58 \%$.

To move to the index of governance cleared, must add an important clarification. Indeed, the most used governance indicators are composite indicators based on perceptions. Even the most carefully constructed composite indicators suffer from limitations that their users seem to ignore. The company needs greater transparency both in production and in the use of these indicators.

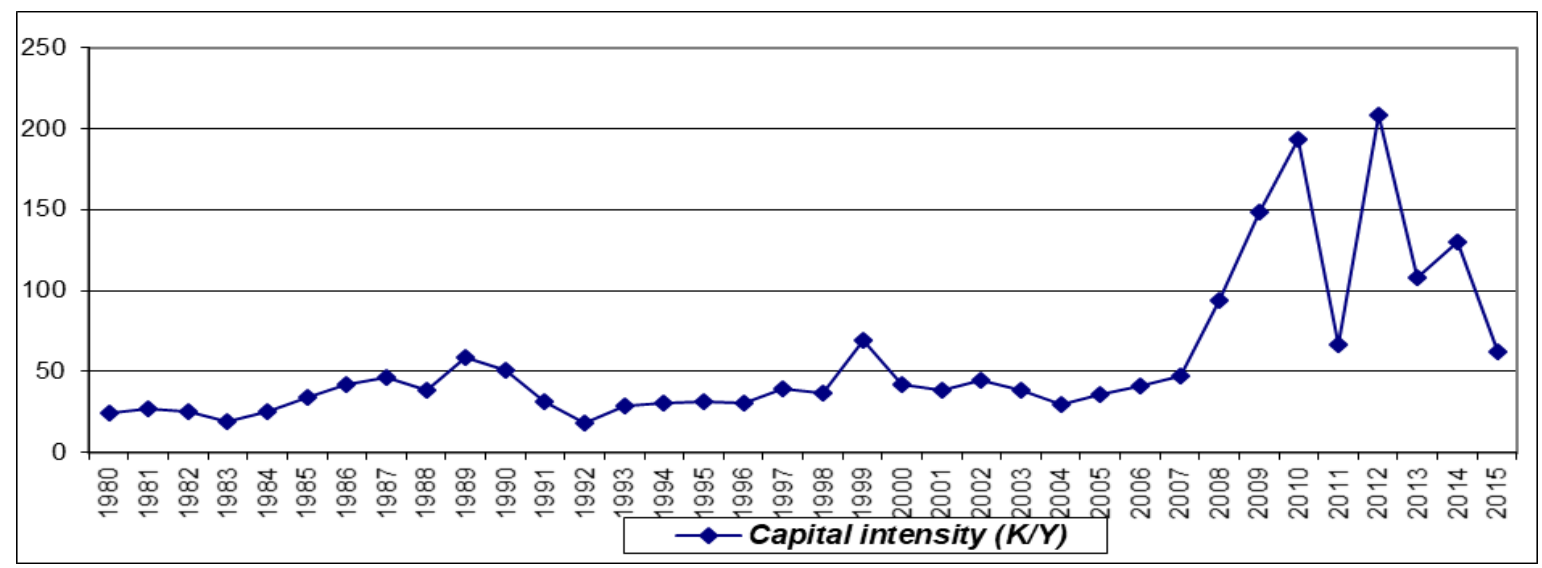

Figure 3. Evolution of capital intensity 


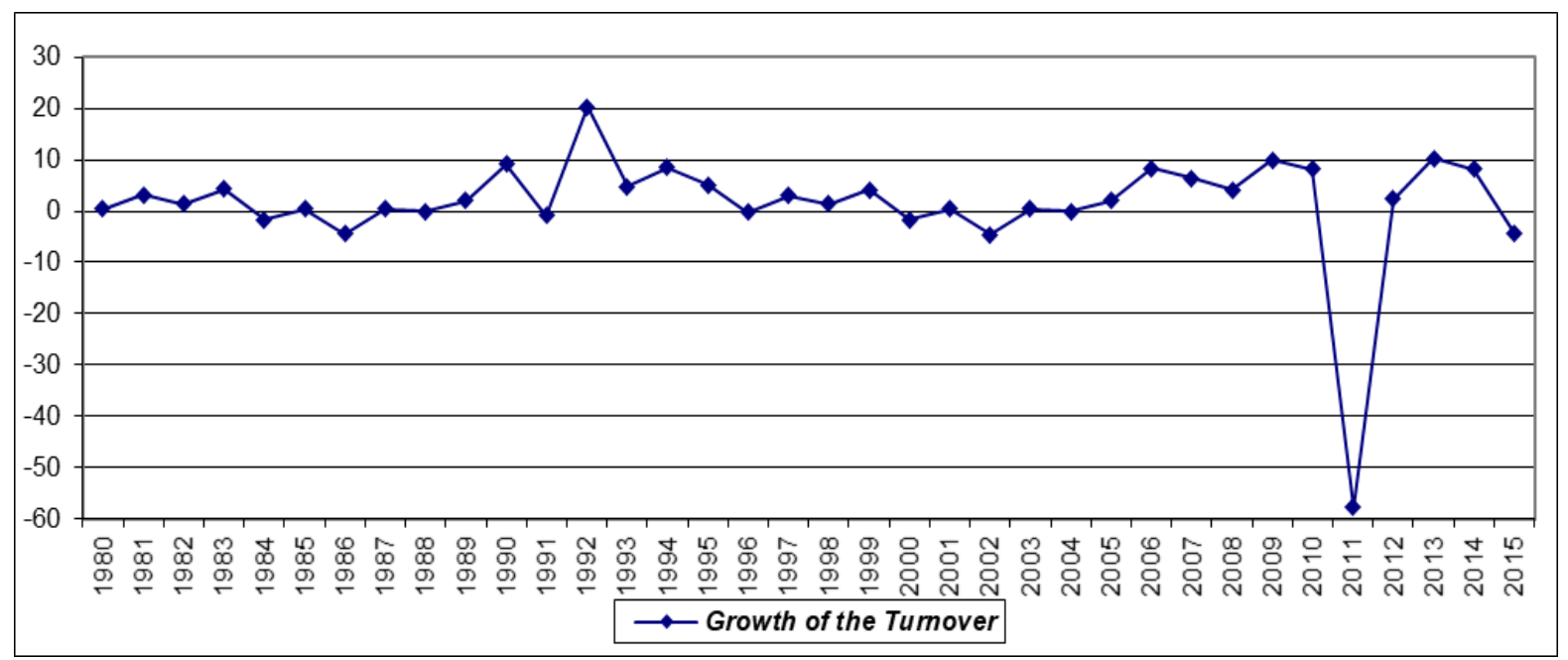

Source: Estimates of the author of the database.

Figure 4. Evolution of the rate of growth of the turnover

Table 2. Descriptive analysis of estimated governance index

Source: Estimates of the author of the database.

\begin{tabular}{l|ll}
\hline \multicolumn{1}{c|}{ Designation } & & Governance index \\
\hline Average & $44.31 \%$ & $25.46 \%$ \\
\hline Standard deviation & $16.79 \%$ \\
\hline Minimum & $100 \%$ & \\
Maximum & & \\
\hline
\end{tabular}

Based on the model 3 above, author were able to identify a governance index and represent its evolution in graph 5 . This index shows an average of $44.3 \%$ with an important deviation of $25.5 \%$. In general, the SNCFT society suffers from a problem of governance, with the exception of a few years where this index shows high scores. From these results, author still confirm that the best time is between the middle of the years 2000 and 2010 . The recovery from 2012, we always attribute it to a political factor rather than greater awareness for the improvement of corporate governance. The proof is always in the decline following years from $84.9 \%$ in 2012 to only $22 \%$ in 2015 .

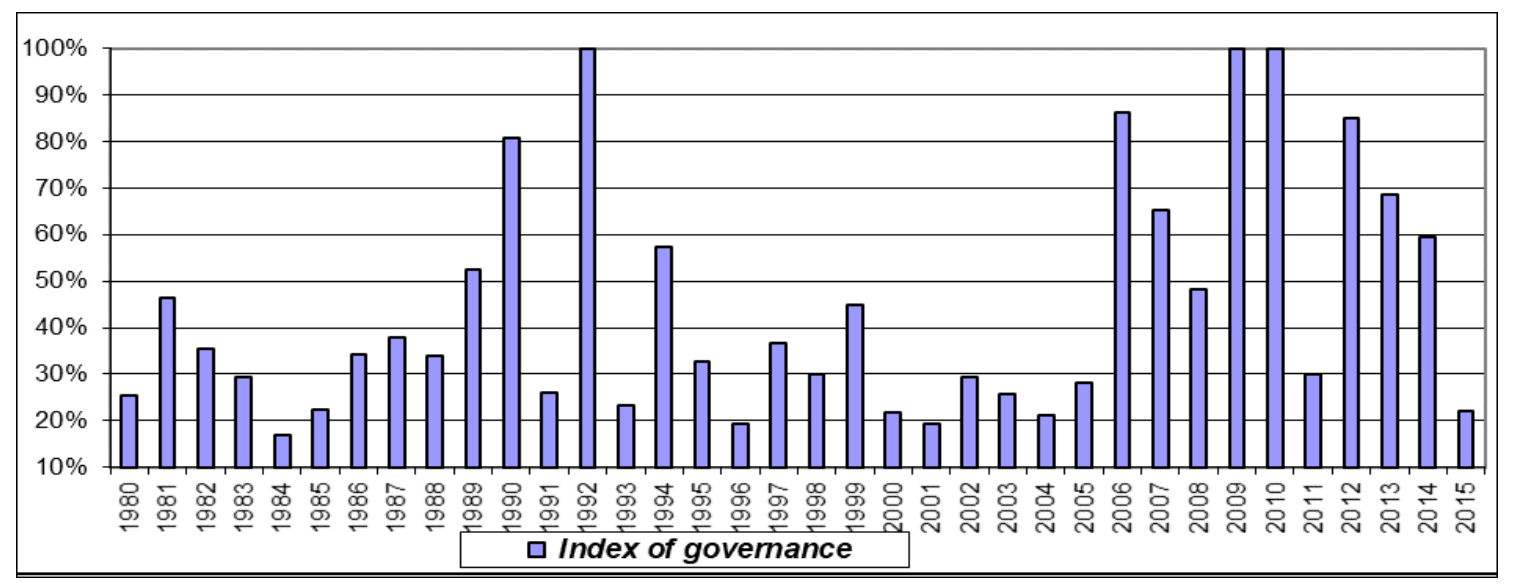

Source: Estimates of the author of the database.

Figure 5. Estimated SNCFT Governance index 
The results say that corporate governance remains weak as a whole compared to the needs of national public policy. This confirms the diagnosis previously made. Indeed, our analysis of the system of governance within the SNCFT, has left to find significant problems in the governance mechanisms related to the opacity of the information, to the weakness of the State-shareholder service and in particular to the failures of control systems.

\section{DISCUSSION}

Looking for indicators of governance at the level of a public company in Tunisia is a very difficult task. Indeed, the assessment of governance implies transparency and access to information that are almost utopian. This is the first indicator of poor governance. Other indicators linked to the control system, to the Board of Directors and to the State-SNCFT program-contracts, can be indicative of the governance within this company.

\subsection{Opaque transparency and faulty information}

A lack of transparency characterizes the management system of SNCFT like any public company in Tunisia. According to the recent World Bank report (2014) "The public enterprise sector continues to suffer from a lack of transparency for stakeholders, (...) which is not conducive to good governance" (pp. 11). By consulting the official website of SNCFT, it is impossible to find information (apart from train schedules and other low added value information) that can inform stakeholders about the situation or the functioning of the company. Thus, not only is the amount of information available far from sufficient, but its quality is poor. However, the publication of information, of sufficient quality and quantity, is the very foundation of a favorable environment for SNCFT. The presence of a shareholder State function institutionally crumbled accentuates this failure in terms of transparency.

\subsection{Institutional fragmentation of the State shareholder}

The weakness of the shareholder function and the multitude of units in charge of monitoring public companies is a characteristic common to all public companies in Tunisia. By following a decentralized model, SNCFT operates in an institutional framework divided between several ministries, with a hegemonic power of the ministry of supervision. The supervising ministry, whose main responsibility is to supervise the SNCFT, intervenes in an important way in the decision-making of the company and in the legal framework. There is a confusion in its supervisory role that brings together the function of shareholder and controller of the public interest, and even of economic and social development. This confusion emanates from the entanglement of the roles of the state. Indeed, there is no clear, well-defined conception of the prerogatives of guardianship. The shareholder function is not only ambiguous, but also not applied as it should be. The shortcomings that characterize the shareholder function affect all the institutions of the chain.

The fragmentation of the shareholder function between several ministries, accompanied above all by the domination of guardianship, is an obstacle to the autonomy of management of SNCFT. In addition, fragmentation among several ministries results in a dilution of responsibilities, and systematic inconsistency. The dilution of responsibilities is even more prejudicial when accompanied by a scattering of rare skills. This weakness of the State shareholder function is all the more evident with the evaluation of the program contracts established between the State and SNCFT. These program contracts linking SNCFT to the State deemed by law to reflect the strategic orientations of the State. In reality, these contracts (if they exist) have deficiencies that can be located at several levels.

Firstly, the State and SNCFT do not systematically establish these program contracts. Secondly, the improvement of the company's situation after a program contract does not mean that the latter has achieved its objectives. This gap which constitutes a breach of the terms of the contract is never sanctioned, which removes the commitment aspect that characterizes the contracts. The lack of respect for the terms of the contract concerns the SNCFT and the State. In other words, contracts have rather the aspect of project. Finally, a Board meeting never discusses these contracts. It was always a point treated among others. In addition, their follow-up present deficiencies related on the one hand, to the problem of lack of information dealt with above, on the other hand to the failures of the control system. 


\subsection{A control system failing}

Three major failures of SNCFT's control system can explain its inability to improve efficiency.

Firstly, on the control side, there is a focus on the shape more than on the bottom. The compagny privileges the control of the procedures compared to that of the results. This explains the inefficiency of these procedures in determining SNCFT's difficulties. The lack of transparency mentioned above, handicaps the control, reduced to a simple follow-up of the procedure. According to the report of the World Bank, the skills of controllers in Tunisia are limited, which prevents them from carrying out their mission in the face of asymmetric information (as cited in World Bank, 2014, p. 20).

Secondly, the controlers have the status of inspectors recruited by the National School of Administration, and have the "rank-function" to carry out their mission. Except that in practice, they face several obstacles. In fact, supervisors are often handicapped in their mission by the hierarchical power in their ministry, or at the level of the first ministry, and depend on the orders of mission that they issue to them. The only control body that escapes this dependence is the court of accounts by its status of magistrate.

Thirdly, a lack of coordination between the different bodies of control is detectable and caused by mission orders which are not in the program, and which disrupt the scheduled tasks. In addition, given the number of StateOwned Enterprises to control, membership of the various control external appears insufficient to achieve this mission. For this reason, the SNCFT could not benefit from a thorough and regular control of its accounts and financial management. The inadequacy or inefficiency of internal audit services aggravate this failure.

\subsection{A weak Board}

An imbalance characterizes the constitution of the board of SNCFT. In fact, out of thirteen members, six are representatives of the ministries and two representatives of the government. This domination, if it hides a political appointment, is all the more prejudicial to the effectiveness of the activity of the council based on a political choice and not on criteria of competence. In addition, departments are inclined to become involved in SNCFT's operational decisions, thus limiting the role of the Board of Directors to a mere instrument in the service of a department.

Regarding the members of the Board of Directors of the SNCFT, as for other public companies, it is clear that they do not grant the importance required for their participation. Indeed, for most it is additional salary rather than an effective participation in the defence of the interests of the State. In addition, the power of the Board of Directors is limited, since in reality the appointments of the SNCFT leadership escape him. The guardianship authority must approve all decisions of the Board. These practices are inconsistent with the rules of good governance.

Another practice contrary to the rules of good governance is the cumulation of functions. Indeed, the Chief Executive Officer of the SNCFT ensures both the function of Chairman of the Board and General Manager of the company. This practice leads automatically a conflict of interest and often leads to derivatives (Aquilera et al., 2016). The possibility of derivatives is all the greater since there are no conditions of appointment to the title of Director as seniority, age, or a specific skill. Criteria specified in the Act, are membership in the Board of Directors, the Tunisian nationality, experience during at least five years and exercise as public official with the category.

All these shortcomings both in terms of the state shareholder function and in the control systems, the lack of transparency or the weakness of the board of directors, are indicators of poor governance within SNCFT. With such failures in governance, the inefficiency of SNCFT and its inability to recover its financial position, become obvious. This confirms the link between inefficiency and governance. 


\section{CONCLUSION}

Governance system includes firm's internal control mechanisms resulting from shareholders, the Board of directors or executives as well as external mechanisms related to the market fonctionning. The Board of Directors as internal control mechanism plays a very important role in the reduction of asymmetric information in a way that garanties the integrity of the financial statements.

These control mechanisms reduce the costs resulting from the conflicts between executives and shareholders as well as the opportunistic behavior. In addition, the mechanisms related to regulation, law or financial information can overcome the conflicts of interest between the firm and financial creditors. The combination of the insufficiencies of the information and the failure of the control shows that the public company, suffers from the problems of control collective actionsl.

The analysis carried out at the level of the SNCFT found problems of governance that can explain the society inefficiency. For the governance of the SNCFT, it is possible to undertake a set of measures, which summarized in three key elements:

Firstly, the SNCFT must have management with increased autonomy and accountability of the Board of Directors. That is what requires an overhaul of the legislative framework and a need of transparency and a quality of the information.

Secondly, the SNCFT must have a clear strategy for the achievement of well-designed objectives under a program contract. The latter must materialize a mutual commitment to the achievement of the objectives. The monitoring of achievement, which depends on both external and internal control, needs an improvement by revising the system and improving the functioning of the Board of Directors.

Thirdly, the State shareholder fonction needs clarification to avoid entanglement of the roles of the State and the resulting ambiguity. This function should focus on highlighting the requirement of technical skills to allow proper monitoring.

On a pragmatic level, the interest of this article is twofold. For SNCFT, this research work made it possible to diagnose its difficulties by focusing on the interaction between its inefficiency and the failures of corporate governance mechanisms. Thus, reforms of the system of governance are recommendations allowing the improvement of its deteriorating situation for several decades. In addition to the interest for SNCFT, this research can also concern all other Tunisian public companies, which are as inefficient and face difficulties that may be even more important.

As an extension to this research, author consider the study of the impact of executive remuneration systems on the performance of the public company. The present work could therefore be extended by examining the problems relating to the executive remunération systems which are important in the financing decision and consequently in performance.

\section{REFERENCES}

1. Aquilera, R., Judge, W., \& Terjesen, S. (2016). Corporate Governance Deviance. Academy of Management Journal, 43(1), 1930-3807. https:// doi.org/10.5465/amr.2014.0394

2. Bednar, M., Love, E., \& Kraatz, M. (2015). Paying the price? The impact of Controversial Governance Practices on Managerial Reputation. Academy of Management Journal, 58(6), 1740-1760. https://doi.org/10.5465/amj.2012.1091

3. Berle, A., \& Means G. (1932). The Modern Corporation and Private Property (380 p.). New York: MacMillan.

4. Boycko, M., Shleifer, A., \& Vishny, R. (1996). A Theory of Privatization. Economic Journal, 106(435), 309-319. Retrieved from https:// scholar.harvard.edu/shleifer/publications/theory-privatization

5. Charnes, A., Cooper, W., \& Rhodes, E. (1978). Measuring the efficiency of Decision Making Unit. European Journal of Operationnal Research, 2(4), 429-444. http://doi.org/10.1016/0377-2217(79)90229-7

6. Charreaux, G. (1996). Vers une théorie du gouvernement d'entreprise. In Naciri, A. Traité de gouvernance corporative: Théories et pratiques à travers le monde (pp. 421-469). Canada: Presses Université Laval. Retrieved from https://bitly.su/fi1IuL 
7. Charreaux, G. (2006). Théories de la gouvernance : de la gouvernance des entreprises à la gouvernance des systèmes nationaux. In Naciri, A. Traité de gouvernance corporative: Théories et pratiques à travers le monde (pp. 57-113). Retrieved from https://urlz.fr/bTaV

8. Clarke, T., \& Branson, D. (2012). The SAGE Handbook of Corporate Governance. USA: SAGE Publications Ltd. http://dx.doi. org/10.4135/9781446200995

9. Daiser, P., Ysa, T., \& Schmitt, D. (2017). Corporate Governance of State-Owned Enterprises: a Systematic Analysis of Empirical Literature. International Journal of Public Setor Management, 30(5), 447-466. https://doi.org/10.1108/IJPSM-10-2016-0163

10. Foss, N., \& Jensen, H. (2018). Managerial meta-Knowledge and Adaptation: Governance Choice When Firms Don't Know Their Capabilities. Strategic Organization, 17(2), 153-176. https://doi.org/10.1177/1476127018778717

11. Grossi, G., Papenfuß, U., \& Tremblay, M.-S., (2015). Corporate governance and accountability of State-owned enterprises: relevance for science and society and interdisciplinary research perspectives. International Journal of Public Sector Management, 28(4/5), 274285. https://doi.org/10.1108/IJPSM-09-2015-0166

12. Hayden, G., \& Bodie, M. (2019). Reconstructing the Corporation: A Mutual Control Model of Corporate Governance (SMU Dedman School of Law Legal Studies Research Paper No. 435; Saint Louis U. Legal Studies Research Paper No. 2019-04). Retrieved from https://ssrn.com/ abstract $=3441307$

13. Jensen, M., \& Meckling, W. (1976). Theory of the Firm: Managerial Behavior, Agency Costs, and Ownership Structure. Journal of Financial Economics, 3(4), 305-360. https://doi.org/10.1016/0304-405X(76)90026-X

14. Langlois, R., \& Foss, N. (1999). Capabilities and Governance: The Rebirth of Production in the Theory of Economic Organization. Kyklos, 52(2), 201-218. https://doi.org/10.1111/j.1467-6435.1999.tb01442.x

15. Lehmann, E., Warning, S., \& Weigand, J. (2002). Efficient Governance Structures, Corporate Investment, and Profitability (Discussion Paper No. 02-07). Retrieved from https://www.econbiz.de/archiv1/2008/51465_efficient_governance_structures.pdf

16. Lehmann, E., Warning, S., \& Weigand, J. (2004). Governance Structures, Multidimensional Efficiency and Firm Profitability. Journal of Mangement \& Governance, 8(3), 279-304. https://doi.org/10.1007/s10997-004-1116-Z

17. Lin, J., Cai, F., \& Li, Z. (1998). Competition, Policy Burdens, and State-Owned Enterprise Reform. American Economic Review, Papers and Proceedings, 88(2), 422-427. Retrieved from https://www.jstor.org/stable/116960

18. Nellis, J. (1994). Is privatization necessary? World Bank Viewpoint, No. 7. Retrieved from http://documents.worldbank.org/curated/ en/651121468766245760/Is-privatization-necessary

19. Rezaee, Z. (2019). Business Sustainability, Corporate Governance, and Organizational Ethics (992 p.). New Jersey: John Wiley \& Sons. Retrieved from https://books.google.tn/books?id=u9K8DwAAQBAJ\&hl=fr\&source=gbs_book_other_versions

20. Shleifer, A., \& Vishny, R. (1994). Politicians and Firms. Quarterly Journal of Economics, 109(4), 995-1025. Retrieved from https://scholar. harvard.edu/files/shleifer/files/politicians_firms.pdf

21. Shleifer, A., Vishny, R. (1997). A Survey of Corporate Governance. Journal of Finance, 52(2), 737-783. https://doi. org/10.1111/j.1540-6261.1997.tb04820.x

22. The World Bank Group (2014). Corporate Governance of State-Owned Enterprises: A Toolkit (391 p.). Retrieved from https:// openknowledge.worldbank.org/handle/10986/20390 